\title{
Innovation of Verbs in Hebrew
}

\author{
Uzzi Ornan \\ Hebrew University f Jerusalem \\ Hebrew Linguistics \\ Technion, I.I.T. Haifa \\ Computer Science \\ Technion City, Haifa, 32000, Israel \\ ornanu@gmail.com, ornan@cs.technion.ac.il
}

\begin{abstract}
Absract
In modern time a lot of connections developed among various nations, and people became acquainted with several languages. New conceptions move from their origin in a certain language to another surrounding. Hebrew also adopted many new words from foreign origin, but there is a difficulty to adopt foreign verbs in Hebrew, since a Hebrew verb must be in a certain pattern. This short paper explains how a special device has developed in the Hebrew grammar to cope

with this need.
\end{abstract}

\section{Empty squares for innovations}

Many squares in the array are actually empty. They may become full if new words are needed to be introduced into the language. Usually it happens if a speaker does not find a word that expresses his/her idea. He/She chooses a proper root, and by looking for proper pattern, a new word is produced and from here it shifts into the dictionary (described in Figure 2).

\section{Verbal and nominal expressions}

Languages have both verbal and nominal expressions. Speakers sometimes need both. In order to express an idea which contains both a noun and a verb, it is possible to use a "general purpose" verb, which expresses a general meaning of doing, such as do, make, or act etc., and relate it to the noun. Here are some expressions in Hebrew: First, general purpose Hebrew verbs:

$$
\begin{aligned}
& \text { lip }^{\varsigma} \text { ol }=\text { to act, } \\
& \text { le-bacce }{ }^{\varsigma}=\text { to perform, } \\
& \text { la- }{ }^{\varsigma} \text { sot }=\text { to do, to make. }
\end{aligned}
$$

And some examples of actual use:

la-'Śsot ma`amaççim = to make efforts,

le-harim telepon $=$ to pick up a

telephone,

lišloah mibraq = to send a telegram,

la- ${ }^{\text {' }}$ rok biqqur = to pay a visit.

\section{Same root for both}

It is very common that both the verbal and the nominal expressions be of the same root, such as: 
liktob miktab $=$ to write a letter (root: $k^{\prime} t^{\prime} b^{\prime}$ )

lsapper sippur $=$ to tell a story (root: $\left.s^{\prime} p^{\prime} r^{\prime}\right)$.

Such use of expression is specially significant in Hebrew for a need to add an adjective to the noun while the real meaning is to add an adverbial description to the verb. E.g., by the nominal phrase "important decision" such as in Hebrew : le-hahlit hahlața hašuba (root: $\left.h^{\prime} l^{\prime} t^{\prime}\right)=$ to decide an important decision. Here both noun and verb are of the same root. Sometimes the verbal expression itself includes the idea of the nominal expression, such as,

le-habriq = lišloh mibraq (to telegraph, or to send a telegram),

le-hištakker= lištot le-šokra (to drink up

to toxication),

le-hitraggez $=$ le-habbi ${ }^{\varsigma}$ rogez $($ to express anger).

\section{Foreign nouns need "squeezing"}

But what about foreign nouns? Modern world offers a lot of contacts for speakers of various languages, and Hebrew also got a lot of foreign nouns from many languages. These nouns are not included in the array. and what is more important, they do not have roots, while Hebrew speakers are used to connect nouns and verbs, preferably through common roots. A special procedure developed in Hebrew grammar, which produces roots from foreign nouns. This procedure is "squeezing": We squeeze the noun and get its vowels out ${ }^{1}$. What remain is its consonants only.

This sequence of consonants is considered to be used as a new root. The new root is put in a new line in the list of roots at the root-pattern array, and of course on the spot a lot of new empty squares appear along the line of the new root. Some of them are verbal patterns. Now one can choose a proper verbal pattern and here a new Hebrew verb appears.

\footnotetext{
1 See, Ornan 1976 (in Hebrew), Ornan 1990 p. 88 .
}

\section{Root is sequence of consonants}

For example, a new instrument is invented somewhere in a foreign country and has been brought to the Hebrew speakers together with its name: It is the telephone. We have mentioned it above in the first appearance in the idiom le-harim telepon, but sometimes after that we find another word which conveys the same meaning, i.e., le-talpen = to phone. This verb may appear of course in various verbal structures, such as

tilpanti $=$ I phoned,

talpenu elay $=$ please phone me, etc.

The verb appeared as a result of the squeezing process. From telephone we got the sequence of consonants $t l p n$. and that was enough to add a new line in the root lines of the root-pattern array. ( [p] and [f] relate to the same phoneme /p/ even in Modern Hebrew.)

\section{Squeezing is original procedure}

This procedure of squeezing has been active even in ancient times. It can be seen in the Greek word which entered into Hebrew as well as to many languages - basis. We have a Hebrew verb based on the $\operatorname{root} b s s$, which was squeezed from basis in ancient time and is being used since Mishnaic Hebrew until modern time.

\section{Squeezing in Hebrew increased}

In Modern time squeezing seems to increase. Many new ideas appeared in the wide world, and Hebrew did not stay behind. Beside other ways of innovation of new words from wide world origin, we find a lot of new words, especially verbs, which have been coined by squeezing. See for example what happened to English words such as compilation, debug, format, fax, discuss, Pascal, Pasteur, Rentgen. They all passed through squeezing, even if some of them are not necessarily nouns. For example,

$$
\begin{aligned}
& \text { le-qampel }=\text { to compile }(\text { code }), \\
& \text { le-dabbeg }=\text { to debug, } \\
& \text { le-farmet }=\text { to format, } \\
& \text { le-faqses }=\text { to send a fax note } \\
& \text { le-dasqes }=\text { to discuss, to talk } \\
& \text { le-fasqel }=\text { run a Pascal code, } \\
& \text { le-faster = pasterize, } \\
& \text { le-rantgen = to X-ray. }
\end{aligned}
$$




\section{Squeezing of Hebrew words}

Next development of the squeezing procedure is that it began to work also on Hebrew words. It happened whenever a speaker feels that the old root does not satisfy his/her needs. A good example is the noun mispar which exists in the rootpattern array, with the root $s^{\prime} p^{\prime} r^{\prime}$ and pattern $m i-a-$. Its meaning is "a number", and the verb sapar means "to count". Now what happens when you need to express the idea of giving numbers to a bunch of pages or names in a long queue. The verb sapar "count" is not proper. So the noun mispar has been squeezed and a new root, $m^{\prime} s^{\prime} p^{\prime} r{ }^{\prime}$ appeared in a new line at the array, producing a new verb le-masper $=$ to give numbers. Another example is himhiz. Its root $m h \underline{z}$ squeezed from maḩze = stage play, a noun of root $h^{\prime} z^{\prime} y^{\prime}$ (The m is from the pattern). The procedure is so strong that even a sequence of two adjacent words may be squeezed such as "'ad ka`n" which means "up to the present". This idiom was squeezed, and we got a new root: $\varsigma^{\prime} d^{\prime} k^{\prime} n$ ', from which a verb as well as an adjective appeared:

le- ${ }^{\varsigma}$ adken et ha-hadašot $=$ to update the news, or

ha-ti“ur lo` mindkan = the description is not uptodate. ${ }^{2}$

2 The squeezing procedure suggestion explains the connection between verbs and their origin much easier and nicer than the efforts done by Outi Bat-El, 1994. She speaks about "extracting", which is the exact "squeezing" described in Ornan, 1976 and Ornan, 1990 (without mentioning them), but tries to adopt it to another theory based on four elements (by McCarthy 1981) which includes adding vowels in a separate procedure, without including any formative consonant to a pattern, while the suggested approach here is based on two elements (pattern and root) only, and we include patterns which may contain consonants. Some needed procedures for correcting

\section{References}

Bat-El Outi, 1994. Stem Modification and Cluster Transfer in Modern Hebrew. Natural Language and a LinguisticTheory 12, pp. 571-596

Bolozky, Shmuel 1978. Word Formation Strategies in the Hebrew Verb System, Denominative Verbs. Afroasiatic Linguistics 5:3 pp. 111-136.

McCarthy, John. J., 1981. A Prosodic Theory of Nonconcatenative Morphology. Linguistic Inquiry 12. pp. $373-418$

Ornan, Uzzi. 1976. על יצירת שורשים חדשים (on generating new roots). Leshonenu- la- ${ }^{\varsigma} a m$, Academy of Hebrew Language, Jerusalem, Vol 27, pp 254-267.

Ornan, Uzzi. 1983. תצורת המילה העברית כיצד (How do we build a Hebrew word). Bar-Asher et al. (editors), Studies in Hebrew dedicated to Ze'ev Ben-Haiim, Magnes Press, Jerusalem, pp. 13-42.

Ornan, Uzzi. 1990. Machinery for Hebrew Word Formation, Martin Charles Golumbic (ed), Advances in Artificial Intelligence, SpringerVerlag, pp. 75-93.

Ornan, Uzzi. 2003. המילה האחרונה (The Final Word), University of Haifa pub, pp. 103-126. various new roots are dealt with in Ornan, 2003 pp. 110-116. 


\begin{tabular}{|c|c|c|c|c|c|c|c|}
\hline $\begin{array}{l}\text { pattern } \\
\text { root }\end{array}$ & -a_a_ & _i__e_ & ma_e_ & hit_a_e- & ${ }_{-}^{a_{-}}$ & ta_u_a & hi_i_ \\
\hline psq & pasaq & pisseq & mapseq & hitpasseq & psaq & - & hipsiq \\
\hline gmr & gamar & gimmer & - & - & gmar & - & - \\
\hline ḩbr & habar & hibber & maḥber & hithabber & - & taḥbura & - \\
\hline 'bd & 'abad & sibbed & - & - & - & - & hi'bid \\
\hline prsm & - & pirsem & - & hitparsem & - & - & - \\
\hline țlgrp & - & țilgrep & - & - & - & - & - \\
\hline
\end{tabular}

Figure 1: Part of Root-Pattern Array

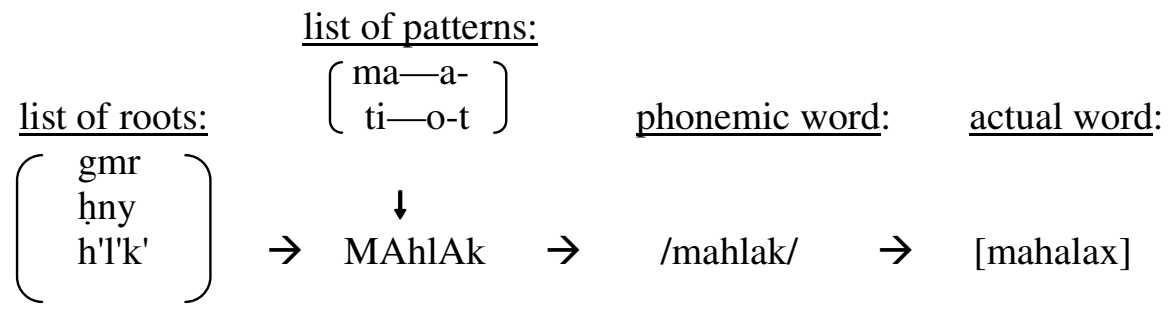

Figure 2: Illustrating part of the generating algorithm 